\title{
Increasing students' motivation by integrating projects on foreign languages into learning process
}

\author{
Svetlana Ignatova ${ }^{1}$, Irina Bobykina ${ }^{1}$, and Elmira RKoleeva ${ }^{1 *}$ \\ ${ }^{1}$ Chelyabinsk State University, Brat'ev Kashirinyh str., 129, Chelyabinsk, 454001, Russia
}

\begin{abstract}
The article reveals the influence of extracurricular projects in a foreign language on the students' motivation in non-linguistic areas of university education for learning a foreign language. Extracurricular projects include Olympiads, conferences and various competitions for translation, essays, videos and similar types of extracurricular activities. The article reveals the illumination of the problem of motivation in the psychological and pedagogical community and gives various points of view on the factors that contribute to increasing motivation for learning a foreign language through extracurricular projects. A survey of students with non-linguistic specialization of the university revealed the key positive and negative factors that determine the attitude of students to such projects. The insignificant number of project participants is explained by the lack of awareness among students and fear of failure. The factors encouraging participation were the interest in the format of the event, the expected benefits for professional development, the support of the environment and a sense of belonging to the faculty. On the basis of the results obtained, recommendations are given to increase the motivation of students to learn a foreign language through participation in projects in foreign languages, and the need to integrate extracurricular academic activity into the educational program is substantiated.
\end{abstract}

\section{Introduction}

The ability to communicate in a foreign language is a universal and inalienable competence that a graduate of any Russian university must master. According to the curricula of educational programs in non-linguistic areas of specialization at the university, the discipline "Foreign language" is a short-term course, which necessitates the intensification of the learning process in order to ensure that students achieve the result of foreign language education - mastering the ability to communicate in a foreign language. As evidenced by the research results, the quality of development of foreign language competence depends on 4 groups of factors: personal, sociocultural, cognitive and intralingual. Among the personal factors, motivational ones stand out. [1] To increase the motivation for learning foreign languages by non-linguistic students, numerous projects of various levels (all-Russian, international, regional, inter-university) were introduced: Olympiads, translation contests, essay contests, video contests, conferences, etc.

The issue of motivation is considered in the works of many Russian and foreign psychologists and educators, such as: L.S. Vygotsky, A.F. Lazursky, A.N. Leontiev, A.K. Markova, A.A. Rean, S.L. Rubinstein, J. Atkinson, W. James, A. Maslow, W. Henning et

\footnotetext{
* Corresponding author: elmira.koleeva@yandex.ru
} 
al. A. Maslow indicated in his study of motivation that most of the information about human motivation was obtained from the observation of psychotherapists for people with neuroses and other disorders and called for the study of healthy motivation in people with strong vitality. [2]

Since then, a lot of research has been devoted to motivation in various manifestations of human activity, including teaching foreign languages (I.L.Bim, I.A.Zimnyaya, N.D. Galskova).

Motivation is an important part of different approaches: competence-based learning [3], person-centered approach [4], problem-based learning [5], constructivist learning [6], blended learning [7] and others.

At the moment, the issue of motivation for learning foreign languages is being studied not only in the context of academic studies, but also in the context of students' participation in extracurricular activities. There are several modern research papers considering motivation in the context of extracurricular activities. They study barriers and motivation study within teaching English to adults [8], Speaking Clubs as a kind of extracurricular activity [9], creating a special education environment in teaching a second foreign language [10] or extracurricular creative events within an individual educational trajectory [11]. However, this article studies motivation of ESL-students in context of implementation of extracurricular events into academic environment.

Although nowadays "motivation remains one of our most studied concepts, theories abound, and there is much empirical work to buttress each theory" [12] the pandemic of COVID-19 has started the new age of motivation for learning [13] as it has significantly changed the educational environment.

As for the extracurricular activities of students, it is reflected in different ways in Western and Russian literature. So, in the West, in the framework of extracurricular activities, students work as volunteers, undergo internships, are in amateur clubs with the opportunity to perform at the university and beyond. On the territory of the Commonwealth of Independent States, extracurricular activities are understood as scientific circles, reading clubs, creative contests [14], ie attention is paid to educational aspects rather than the development of competencies, especially in the professional sphere.

In addition to the extracurricular activities of the students themselves, the following components are distinguished: extracurricular work of teachers with students and a system for managing extracurricular activities. [15] The article focuses on the last two components.

Many different projects are held in Russia every year, where students can show their personal and professional qualities. Both the leadership of universities in general and teachers in particular are interested in such events, since the holding of such events, as well as the success of students, has a positive effect on the prestige of the university and the status of the teacher. However, it remains to be seen within the framework of this study to what extent students of universities, especially regional ones, are personally interested in participating in such events.

Traditionally, students are attracted to participate in Olympiads and competitions as part of educational work. In addition, this article examines the main factors influencing the motivation of students to participate in projects within the framework of the discipline "Foreign language", as well as the influence of pedagogical support for students to participate in projects.

Based on the statement of S.L. Rubinstein that "every human action proceeds from one or another motive and is directed to a specific goal; it solves this or that problem and expresses a certain attitude of a person to the environment." [16] The study examines the motives for the participation of university students and their attitude to projects in a foreign language. As evidenced by the results of the analysis of the authors' pedagogical experience and the data obtained by the method of pedagogical observation, one of the 
motives for participating in projects is the attitude towards the university, since the internal feeling of students' belonging to their university community is considered an essential factor in the formation of academic motivation. [17] No less significant factors, from the authors' point of view, are the relationship between the style of interaction between the teacher and the student and the student's choice of the role of an active participant in the educational process or a passive observer. [18] However, the determination of the students' internal motives is of interest to researchers.

Authors expect to prove the idea of Kamo Chilingaryan and Rimma Gorbatenko [19] that different outside contests increase students' learning motivation but not only among law students. We also want our students to be more independent from teachers' mentorship in choosing and preparing to the events in the context of tendency to change the education environment from teacher-centered to learner-centered. [20] Self-efficacy, social comparisons and outcome expectations were chosen as key internal motivational processes. [21]

So, we set ourselves following research questions:

1. to analyze the attitude and motives of students in educational programs of nonlinguistic specializations to participate in projects in a foreign language and their impact on the motivation for learning a foreign language during the period of professional training at the university;

2. to investigate external and internal factors influencing the motivation of students to participate in projects in a foreign language;

3. to determine the need of students for external support of their extracurricular activities in a foreign language.

\section{Materials and methods}

The purpose of this study is to analyze the main factors affecting the motivation of students in educational programs of non-linguistic areas of preparation at the university to participate in projects in a foreign language, as well as the influence of pedagogical support and support of extracurricular activities of students in a foreign language during the period of professional training at the university.

Theoretical methods: analysis of psychological and pedagogical literature on the topic of research, regulatory documents, information letters and provisions on inter-university competitions and Olympiads, experience in teaching. Empirical methods: pedagogical observation, questioning of students of Chelyabinsk State University using Google Forms, processing of survey results by methods of registration and systematization.

The survey consisted of 4 sections:

1. General information

2. Degree of awareness of inter-university competitions

3. Motivation to participate

4. Reasons for non-participation

The questionnaire consisted of both open and closed questions. Participation is voluntary and anonymous.

In the first section, the students indicated the faculty, education level and course of study, gender.

The second section consisted of the following questions:

- What events in a foreign language, held since the beginning of 2021, were you aware of?

- How exactly did you hear about the event?

- Have you participated in any of the above activities? 
Depending on the answer to the last question, the student was redirected to either section 3 or 4.

Thus, the students who took part in the events answered the following questions:

- In which of the events in a foreign language, held since the beginning of 2021, have you participated?

- Why did you decide to participate?

- Have you consulted with someone about your participation?

- Did your participation influence your desire to learn a foreign language?

- Have you participated in activities in a foreign language before?

- Do you plan to participate in competitions in a foreign language in the future?

- What do you think, is it worth including in the foreign language teaching program various extracurricular activities and / or events in a foreign language (Olympiads, competitions, etc.)?

- Have you participated in other non-foreign language activities?

- Did you participate in similar activities when you were in school?

Students who did not participate in any of the activities were redirected to a section with the following questions:

- Why did you decline to participate?

- Have you consulted with someone about your participation?

- Do invitations to participate in events affect your desire to learn a foreign language?

- Have you participated in competitions in a foreign language before?

- Do you plan to participate in competitions in a foreign language in the future?

- Under what conditions would you take part in such events?

- What do you think, is it worth including in the foreign language teaching program various informal activities and / or events in a foreign language (Olympiads, competitions, etc.)?

- Have you participated in other competitions not related to a foreign language?

- Did you participate in similar activities when you were in school?

\section{Results}

For the analysis, we will consider a sample of 7 events of various levels in a foreign language, held since the beginning of 2021 among students of non-linguistic areas of study in Russian universities.

Information about the organizers, objectives, rewards and format of participation is presented in the table.

Table 1. Events held in 2021 among non-linguistic students.

\begin{tabular}{|c|c|c|c|}
\hline Event Title & Organizer & Objectives & Reward \\
\hline $\begin{array}{l}\text { Inter-university } \\
\text { Public Speaking } \\
\text { Competition } \\
\text { \#NewChallenges } \\
\text { \#NewValues } \\
\text { \#NewSolutions }\end{array}$ & $\begin{array}{l}\text { Center for Languages } \\
\text { and Intercultural } \\
\text { Communication, Faculty } \\
\text { of Economics, Moscow } \\
\text { State University M.V. } \\
\text { Lomonosov and } \\
\text { ONARA company, the } \\
\text { official distributor of the } \\
\text { publishing house } \\
\text { National Geographic } \\
\text { Learning }\end{array}$ & $\begin{array}{l}\text { Formation of soft skills } \\
\text { (critical thinking, } \\
\text { communication skills, } \\
\text { poise, creativity) } \\
\text { identifying creatively } \\
\text { gifted students } \\
\text { formation of a new } \\
\text { level of language } \\
\text { competence } \\
\text { increasing motivation } \\
\text { to learn foreign }\end{array}$ & $\begin{array}{l}\text { Participant } \\
\text { certificate: } \\
\text { Pass } \\
\text { Pass with Merit } \\
\text { Pass with } \\
\text { Distinction }\end{array}$ \\
\hline
\end{tabular}




\begin{tabular}{|c|c|c|c|}
\hline & & $\begin{array}{l}\text { languages } \\
\text { leaving the "comfort } \\
\text { zone" }\end{array}$ & \\
\hline $\begin{array}{l}\text { All-Russian } \\
\text { Olympiad for } \\
\text { students } \\
\text { "Prometheus" }\end{array}$ & $\begin{array}{l}\text { South Ural State } \\
\text { University (National } \\
\text { Research University). } \\
\text { Coordination and } \\
\text { control - department of } \\
\text { foreign languages of the } \\
\text { institute of linguistics } \\
\text { and intercultural } \\
\text { communication }\end{array}$ & $\begin{array}{l}\text { Popularization of } \\
\text { scientific knowledge } \\
\text { among students } \\
\text { increasing the } \\
\text { motivation of young } \\
\text { people to learn foreign } \\
\text { languages and world } \\
\text { culture } \\
\text { identification of } \\
\text { knowledge in the field } \\
\text { of foreign languages } \\
\text { association according } \\
\text { to the interests of a } \\
\text { wide range of students }\end{array}$ & $\begin{array}{l}\text { 1st, 2nd, 3rd degree } \\
\text { diplomas } \\
\text { Participant } \\
\text { certificate } \\
\text { By decision and } \\
\text { proposal of the } \\
\text { jury, the } \\
\text { Organizing } \\
\text { Committee may } \\
\text { award additional } \\
\text { nominations and } \\
\text { prizes }\end{array}$ \\
\hline $\begin{array}{l}\text { IV International } \\
\text { essay competition } \\
\text { in English } \\
\text { dedicated to World } \\
\text { Day of Social } \\
\text { Justice -"Everyone } \\
\text { is Equal in the Face } \\
\text { of the Pandemic. } \\
\text { Social Justice: } \\
\text { Problems, } \\
\text { Discussions, } \\
\text { Solutions" }\end{array}$ & $\begin{array}{l}\text { Ural State Economic } \\
\text { University (USEU), } \\
\text { Department of Foreign } \\
\text { Languages }\end{array}$ & $\begin{array}{l}\text { Drawing the attention } \\
\text { of participants to the } \\
\text { problem of social } \\
\text { inequality that arises } \\
\text { before people due to } \\
\text { their gender, age, race, } \\
\text { ethnic or religious } \\
\text { affiliation, culture or } \\
\text { disability; } \\
\text { analysis and critical } \\
\text { understanding of the } \\
\text { problem indicated by } \\
\text { the theme of the } \\
\text { Competition, search } \\
\text { for possible solutions; } \\
\text { increasing interest in } \\
\text { learning English as a } \\
\text { language of } \\
\text { international } \\
\text { cooperation and joint } \\
\text { discussion of global } \\
\text { common human } \\
\text { problems }\end{array}$ & $\begin{array}{l}\text { Diplomas I, II, III } \\
\text { degree } \\
\text { Money } \\
\text { prizes }\end{array}$ \\
\hline $\begin{array}{l}\text { International Video } \\
\text { Competition } \\
\text { "MOViC" within } \\
\text { the framework of } \\
\text { the VII } \\
\text { International } \\
\text { Scientific Youth } \\
\text { Forum in Foreign } \\
\text { Languages "Global } \\
\text { Changes: the View } \\
\text { of Youth" }\end{array}$ & $\begin{array}{l}\text { Siberian Institute of } \\
\text { Management - a branch } \\
\text { of the Federal State } \\
\text { Budgetary Educational } \\
\text { Institution of Higher } \\
\text { Education "Russian } \\
\text { Academy of National } \\
\text { Economy and Public } \\
\text { Administration under } \\
\text { the President of the } \\
\text { Russian Federation" }\end{array}$ & $\begin{array}{l}\text { Development of the } \\
\text { creative and scientific } \\
\text { potential of students } \\
\text { deepening knowledge } \\
\text { of foreign languages } \\
\text { identifying and } \\
\text { encouraging talented } \\
\text { students } \\
\text { creation of social } \\
\text { significance of foreign }\end{array}$ & $\begin{array}{l}\text { Winner diploma } \\
\text { Participant } \\
\text { certificate }\end{array}$ \\
\hline
\end{tabular}




\begin{tabular}{|c|c|c|c|}
\hline & & $\begin{array}{l}\text { language skills } \\
\text { strengthening ties } \\
\text { between universities in } \\
\text { Russia and foreign } \\
\text { countries. }\end{array}$ & \\
\hline $\begin{array}{l}\text { X International } \\
\text { Youth Scientific } \\
\text { and Practical } \\
\text { Conference in } \\
\text { Foreign Languages } \\
\text { "Modern Trends in } \\
\text { World } \\
\text { Cooperation" in the } \\
\text { framework of the } \\
\text { VII International } \\
\text { Scientific Youth } \\
\text { Forum in Foreign } \\
\text { Languages "Global } \\
\text { Changes: the View } \\
\text { of Youth" }\end{array}$ & $\begin{array}{l}\text { Siberian Institute of } \\
\text { Management - a branch } \\
\text { of the Federal State } \\
\text { Budgetary Educational } \\
\text { Institution of Higher } \\
\text { Education "Russian } \\
\text { Academy of National } \\
\text { Economy and Public } \\
\text { Administration under } \\
\text { the President of the } \\
\text { Russian Federation" }\end{array}$ & $\begin{array}{l}\text { Development of the } \\
\text { creative and scientific } \\
\text { potential of students } \\
\text { deepening knowledge } \\
\text { of foreign languages } \\
\text { identifying and } \\
\text { encouraging talented } \\
\text { students } \\
\text { creation of social } \\
\text { significance of foreign } \\
\text { language skills } \\
\text { strengthening ties } \\
\text { between universities in } \\
\text { Russia and foreign } \\
\text { countries. }\end{array}$ & $\begin{array}{l}\text { Diplomas I, II, III } \\
\text { degree } \\
\text { Participant } \\
\text { certificate }\end{array}$ \\
\hline $\begin{array}{l}\text { All-Russian } \\
\text { competition of } \\
\text { written translation } \\
\text { "Found in } \\
\text { translation 2021" }\end{array}$ & $\begin{array}{l}\text { Department of } \\
\text { Linguistics and } \\
\text { Translation, Faculty of } \\
\text { Foreign Languages, } \\
\text { Omsk State University. } \\
\text { F.M. Dostoevsky with } \\
\text { the support of the } \\
\text { Department of Theory } \\
\text { and Methods of } \\
\text { Teaching Foreign } \\
\text { Languages and the } \\
\text { Department of Foreign } \\
\text { Languages for Special } \\
\text { Purposes of the Faculty } \\
\text { of Foreign Languages of } \\
\text { Omsk State University } \\
\text { named after } \\
\text { F.M.Dostoevsky, the } \\
\text { regional branch of the } \\
\text { Union of Translators of } \\
\text { Russia and the Omsk } \\
\text { State Literary Museum } \\
\text { named after F.M. } \\
\text { Dostoevsky }\end{array}$ & $\begin{array}{l}\text { Attracting the attention } \\
\text { of university students } \\
\text { and schoolchildren to } \\
\text { translation issues } \\
\text { improving the quality } \\
\text { of text translation } \\
\text { development of socio- } \\
\text { cultural, foreign } \\
\text { language, translation } \\
\text { and linguistic } \\
\text { competencies in the } \\
\text { field of knowledge of } \\
\text { Russian and foreign } \\
\text { languages }\end{array}$ & $\begin{array}{l}\text { Laureate certificate } \\
\text { Participant } \\
\text { certificate } \\
\text { Individual } \\
\text { participants in the } \\
\text { competition may, } \\
\text { by decision of the } \\
\text { commission, be } \\
\text { encouraged with } \\
\text { diplomas. }\end{array}$ \\
\hline $\begin{array}{l}\text { Regional student } \\
\text { competition } \\
\text { "Beginner } \\
\text { Translator - 2021" }\end{array}$ & $\begin{array}{l}\text { Department of Foreign } \\
\text { Languages of the State } \\
\text { Agrarian University of } \\
\text { the Northern Trans- } \\
\text { Urals }\end{array}$ & $\begin{array}{l}\text { Increasing motivation } \\
\text { to improve } \\
\text { communication skills } \\
\text { in the field of a foreign } \\
\text { language and } \\
\text { intercultural } \\
\text { communication } \\
\text { creating opportunities }\end{array}$ & $\begin{array}{l}\text { Diplomas } \\
\text { Participant } \\
\text { certificates }\end{array}$ \\
\hline
\end{tabular}




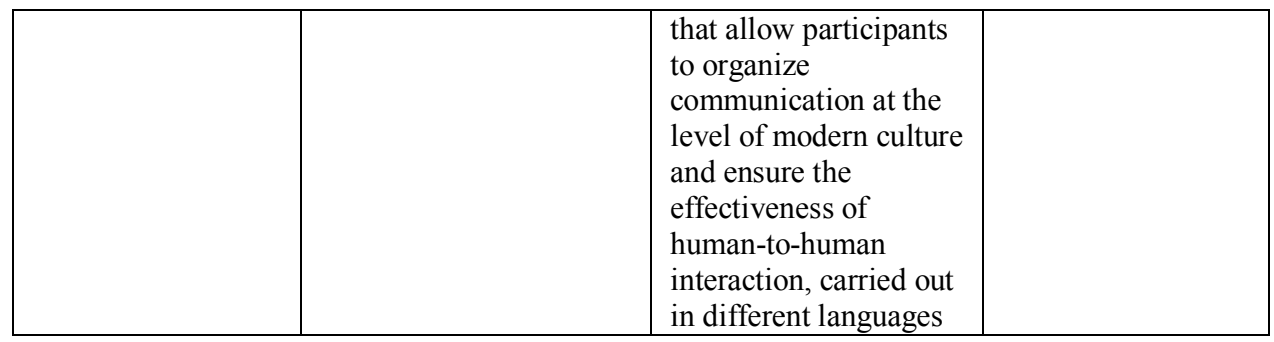

These activities were included in the survey. All events are held online, except for the final round of the Prometheus All-Russian Olympiad.

The survey involved 115 people studying law, biological sciences, economics, management, mathematical and physical sciences at the bachelor's, specialist's and master's degrees.

The level of awareness of the events is shown in Figure 1.

The graph reflects the number of students who are aware of each event.

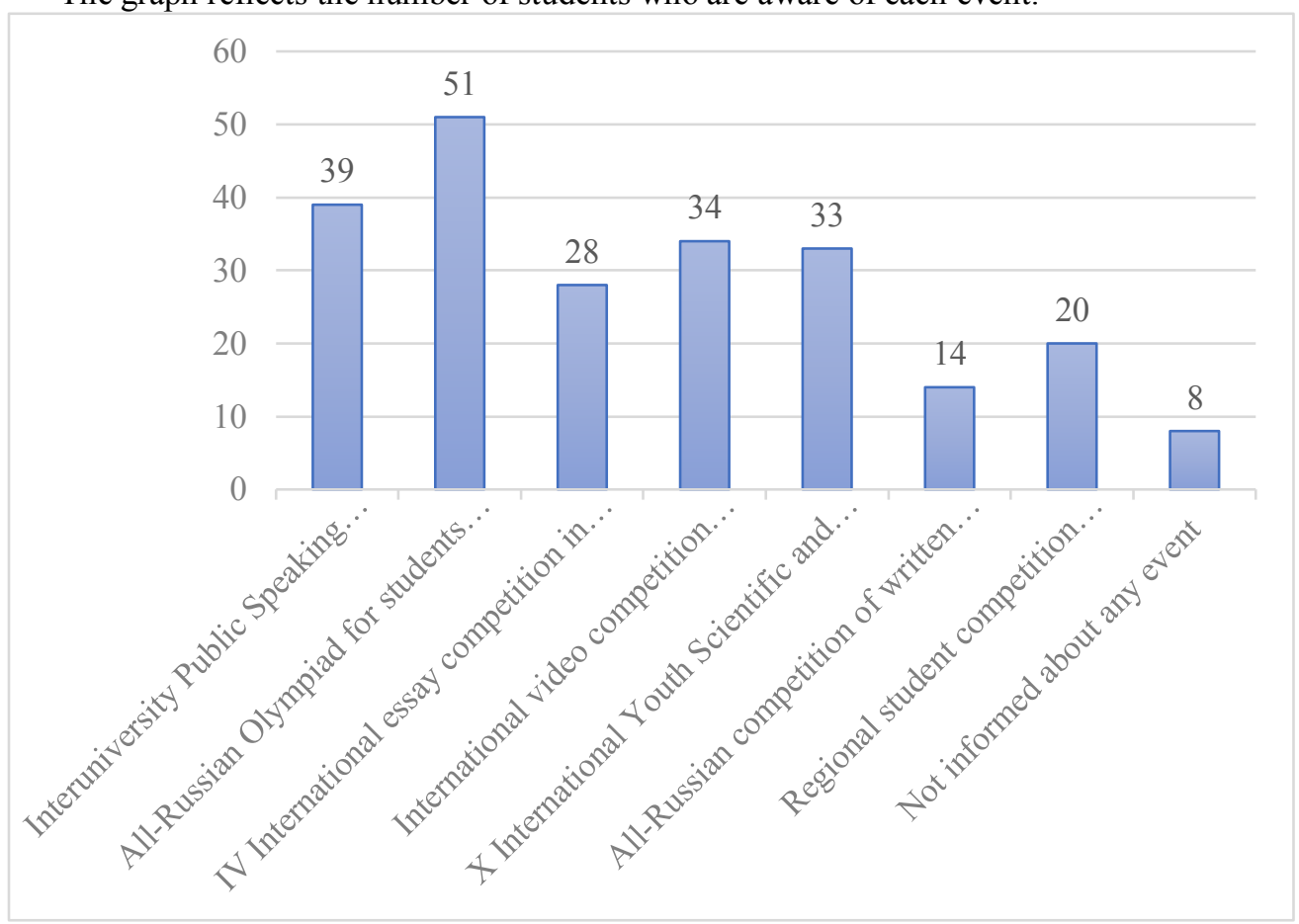

Fig. 1. Awareness of the events

The communication format is shown in Figure 2. The diagram shows the percentage of the ways in which students were informed about upcoming events. 


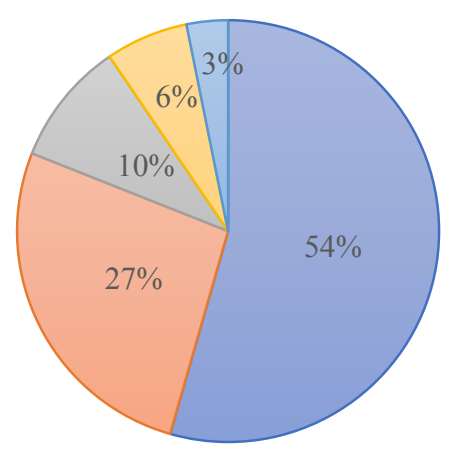

$\square$ The lecturer announced to the group during the lesson

$\square$ The lecturer communicated to the group in an electronic environment (Moodle, Teams)

$\square$ The lecturer informed the group through the group president (Vkontakte, Whatsapp, Viber, Telegram)

$\square$ The lecturer invited me to participate in person

$\square$ You found out about the event on your own

Fig. 2. Awareness format

13 people took part in the events. The largest number of students took part in the AllRussian Olympiad "Prometheus" - 9 people (mostly students of the Faculty of Physics and the Institute of Law). 3 people each participated in the MOViC international video competition and the \#NewChallenges \#NewValues \#NewSolutions public speaking competition. 3 students of the Institute of Law took part in the IV international essay competition. 2 students represented Chelyabinsk State University at the regional student competition "Beginner Translator - 2021". And only 1 student entered the All-Russian competition of written translation "Found in translation 2021". It is noteworthy that the participant of the written translation competition took part in all the events.

The following is a comparison of how participating and non-participating students answered similar questions. 
The factors that influenced participation are shown in Figure 3. The graph shows the number of students who mentioned each factor.

I am interested in the format of the event

I am interested in any activity in a foreign

$$
\text { language }
$$

Participatory experience is useful for my professional development

Participatory experiences are beneficial for my personal development

I am interested in organizers' prizes

I collect certificates for my portfolio

The lecturer gives points for participation

It is nice to represent your university at events

It is nice to represent your faculty at events

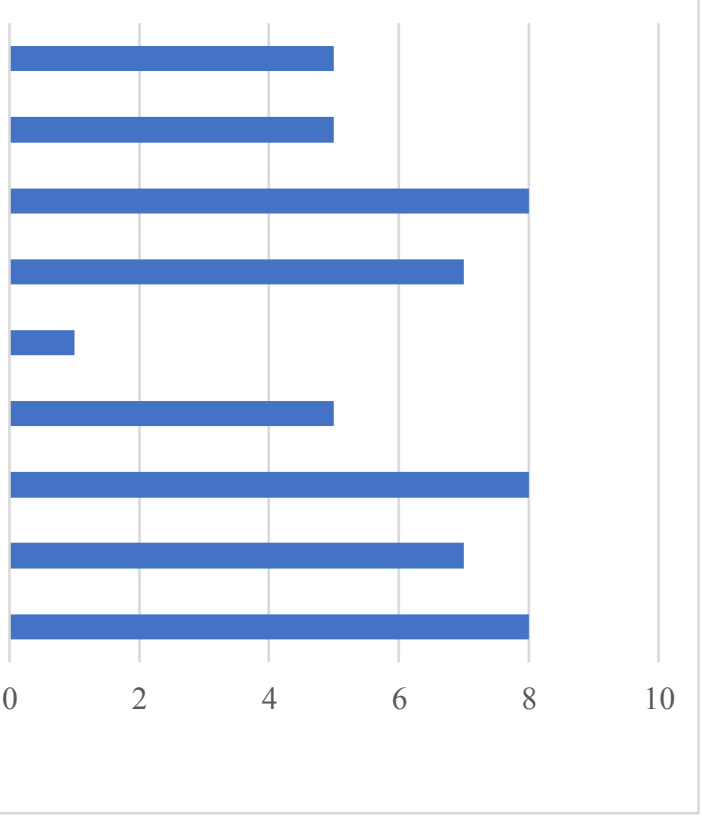

Fig. 3. Factors influencing participation

Among the reasons for non-participation, the answers were distributed as follows (in Figure 4).

The format of the event is not interesting for me

Foreign language is not interesting for me

I see no benefit for my professional development

I see no benefit for my personal development

I am not interested in the organizers' prizes

The lecturer did not motivate me in any way

It is unpleasant to represent your university at events

It's unpleasant to represent your faculty at events

I'm afraid I won't be able to handle it

I don't have enough time for participation

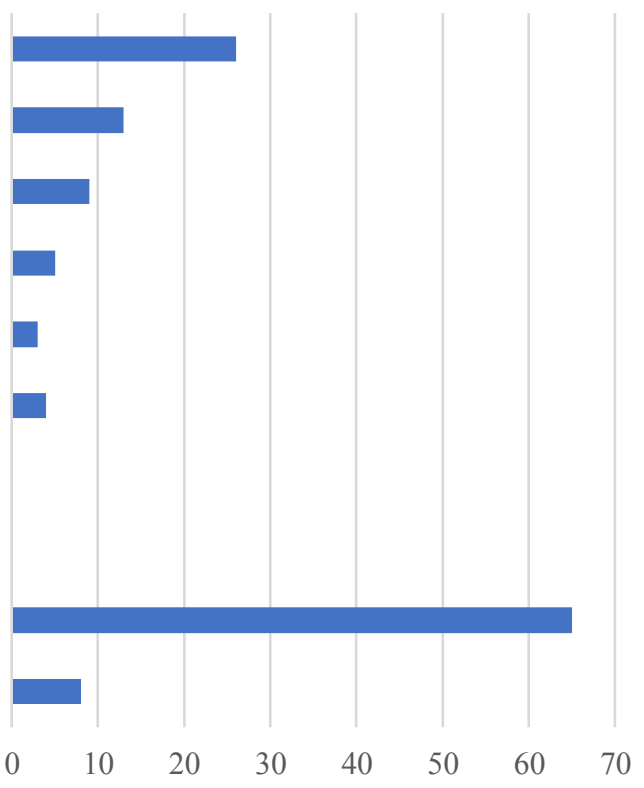

Fig. 4. Reasons for non-participation

The range of responses regarding the influence of the environment on students' desire to participate in activities can be seen in Figures 5 and 6. 


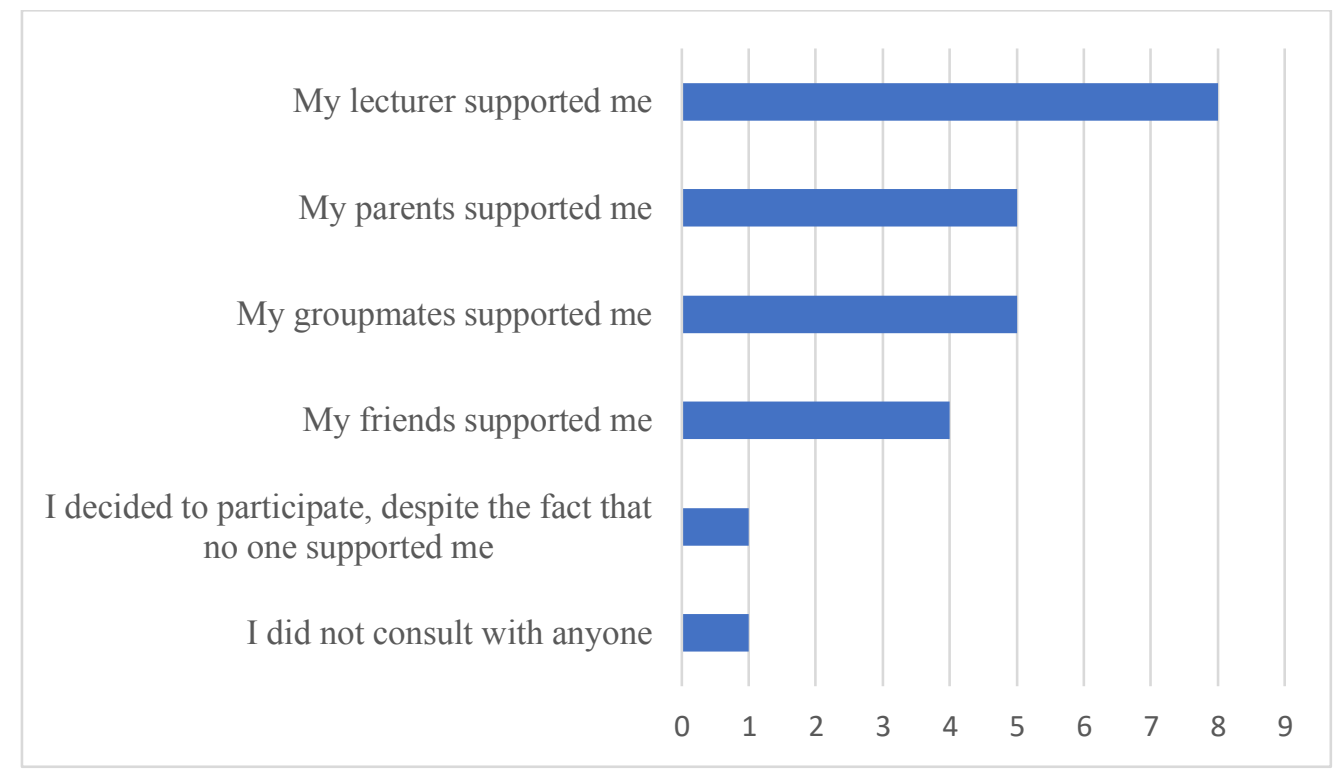

Fig. 5. Answers of students who participated in the events about the other people's support

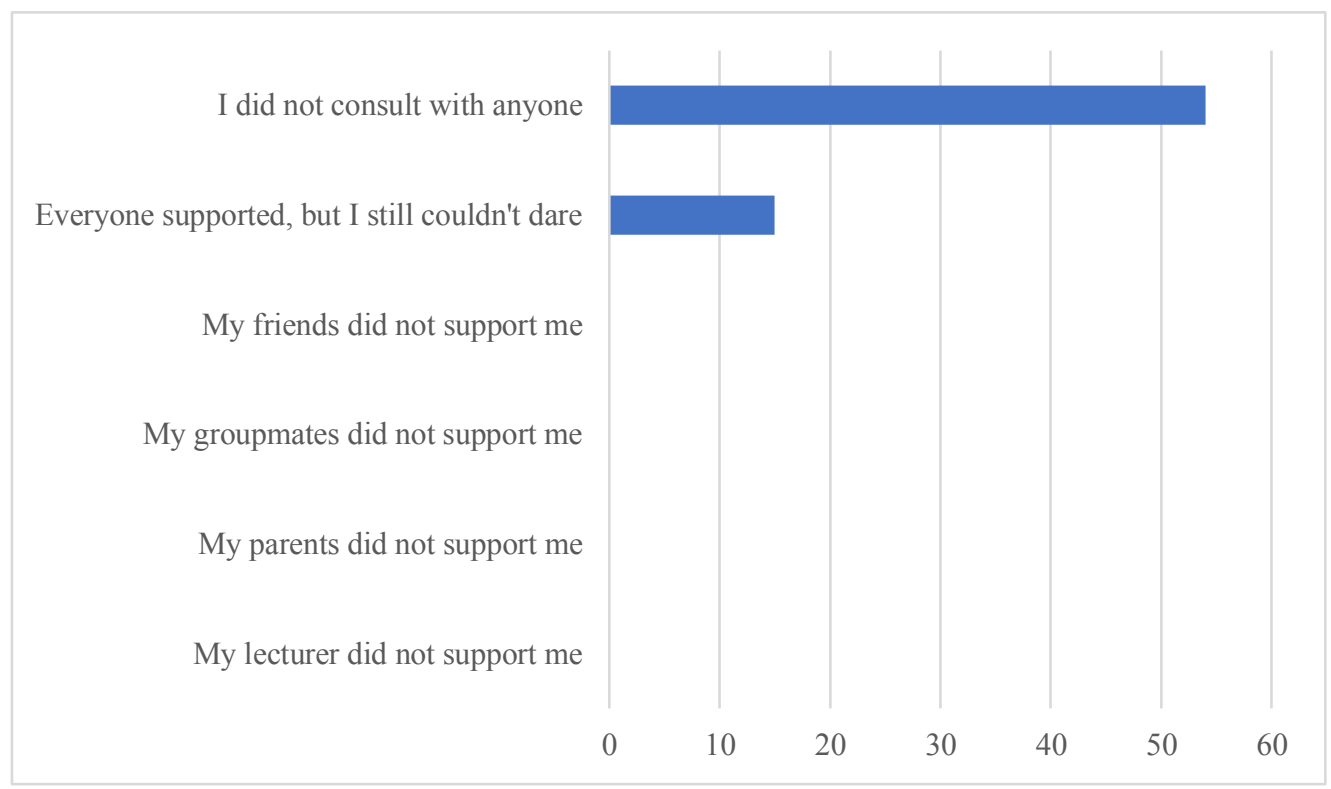

Fig. 6. Answers of students who refused to participate about the other people's support

The distribution of answers to the remaining questions is shown in Figure 7. Here is the percentage of positive answers of two groups of students. 


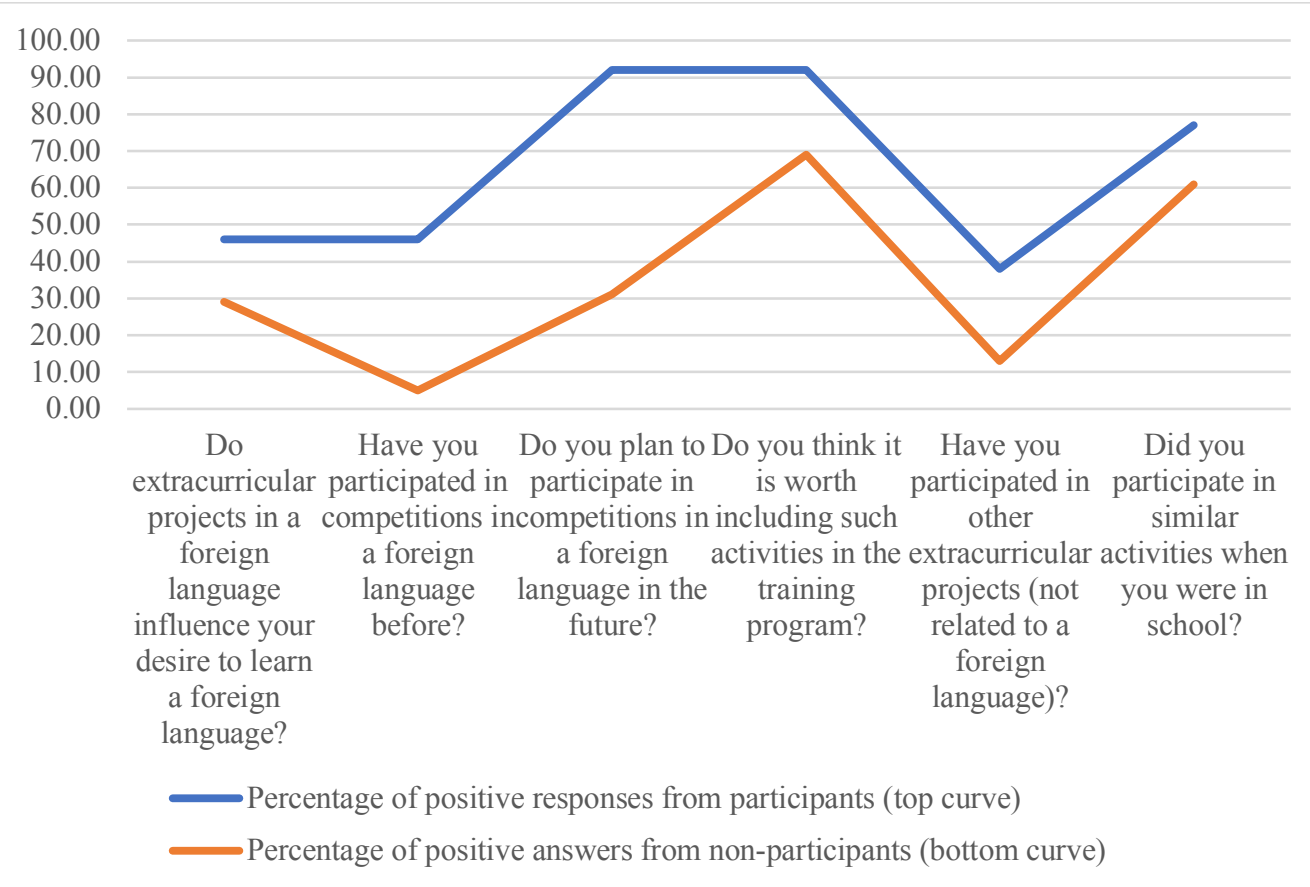

Fig. 7. Percentage of positive answers to questions about motivation for learning a foreign language, experience of participating in similar events and plans for further participation.

\section{Discussion}

Observations show that in recent years, activities have become more accessible. The situation with the spread of coronavirus infection has transferred many events from face-toface format to the online space, greatly simplifying the organization of participation in events. From now on, there is no need to organize support, since in many projects students can take part in their free time, without leaving home, or refuse due to lack of funding.

Nevertheless, the results of the survey confirm the low activity of students of the regional university in projects, and not only in a foreign language. Although, in general, students have a positive attitude towards the events, including making plans for further participation. Interest is noted both among those who have already taken part and among those who have not yet decided.

As for the influence of projects on the motivation to learn a foreign language, at the same time on the increase in the ability to communicate in a foreign language, less than half of the respondents noted this factor. However, participation in such projects significantly motivates students to further extracurricular activities, which ultimately has a positive effect on the variety of situations where students can practice their foreign language communication skills. In part, this can help in solving the problem of insignificant hours in the "Foreign language" discipline. While most students would like to see participation in the activities as part of the program.

The main factors encouraging participation were motivation on the part of the teacher, the visible benefits for their professional development and the desire to demonstrate belonging to their faculty.

The main factor hindering participation was the fear of failure. This factor is largely ahead of all others. 
There is also a high dependence of students on the support of the teacher, parents, classmates, friends. After all, the majority refused to participate, without consulting anyone. Conversely, most of those who decided to take part received the support of those around them.

Students' need for support from teachers is manifested in the need to inform about events. Some students report that they would have taken part if they had known. The most preferred format of informing in the classroom seems to be less effective due to the absence of a student for a specific reason or late receipt of information, since classes in FL are held only once a week, which leads to the fact that the student does not have enough time to make a decision and prepare for participation in the project ...

There is a high activity in extracurricular activities during school years, but a sharp decline in the student body. This is due to the more voluminous extracurricular work of school teachers in comparison with university teachers.

Thus, to solve the identified problems and increase the motivation of students to participate in projects in order to involve students in additional activities in a foreign language, the following solutions are proposed.

At the level of the management system of students' extracurricular activities, it is necessary to provide pedagogical support assistnance.

It is recommended to provide information not only about upcoming projects, but also the results of participation in various information sources. Thus, to provide students with moral support, as students are motivated by a sense of belonging to their faculty.

If possible, we recommend to use various channels to inform students about upcoming projects. The trend towards informatization of education contributes to the fact that the teacher can contact students not only offline, but also online. This allows more students to be informed more quickly.

Greater efficiency can be achieved when extracurricular foreign language activities are included directly in the discipline program and take into account participation in projects in the system of point-rating assessment of the results of foreign language education.

\section{Conclusions}

Activities in a foreign language are one of the most effective means of increasing motivation for learning a foreign language and developing the ability to communicate in a foreign language, since they provide additional practice and contribute to the wider use of foreign language skills of non-linguistic students in comparison with organized classes in a limited number. Despite the large selection of activities and their increasing availability, student activity remains insufficiently high. The main problem is the personality factor: lack of motivation and fear of failure. At the same time, students already participating in the events demonstrate high motivation for further participation.

Thus, the results of the study confirm, firstly, the need for timely and high-quality informing students about the events, secondly, the need of students for moral support, thirdly, the inclusion of extracurricular activities in the educational program.

\section{References}

1. N. A. Martynova, V. N. Shashkova, K. A. Vlasov, Perspektivy nauki i obrazovaniya, 6 (42), 142-157 (2019), doi: 10.32744/pse.2019.6.12

2. A. KH. Maslou, Motivatsiya i lichnost', 196 (2014)

3. O. Zaikin, M. Malinowska, N. Bakhtadze, A. Żyławski, Procedia Computer Science, 112, 1092-1101 (2017), doi: 10.1016/j.procs.2017.08.131 
4. K. Xie, V. W.Vongkulluksn, L. Lu, Sh.-L. Cheng, Contemporary Educational Psychology, 62, 2020, doi: 10.1016/j.cedpsych.2020.101877

5. E. Jaleniauskienè, Procedia - Social and Behavioral Sciences, 232, 265 - 275 (2016), doi: 10.1016/j.sbspro.2016.10.014

6. Y. W. Kwan, A. F.L.Wong, International Journal of Educational Research, 70, 68-79 (2015), doi: 10.1016/j.ijer.2015.02.006

7. K. M. Y. Law, Sh. Geng, T. Li, Computers \& Education, 136, 1-12 (2019), doi: 10.1016/j.compedu.2019.02.021

8. Y. Alhasov, A. Verbytska, T. Kolenichenko, Advanced Education, 15, 12-19 (2020), doi: 10.20535/2410-8286.195696

9. O. Demydovych, O. Holik, Advanced Education, 14, 4-10 (2020), doi: 10.20535/24108286.178238

10. M. Kaskova, N. Chernova, O. Ustinova, EDULEARN19: 11th International Conference on Education and New Learning Technologies, 368-374 (2019)

11. V. Kolmakova, L. Ovinova, INTED2017: 11th International Technology, Education and Development Conference, 3984-3991 (2017)

12. J. Hattie, F. A. Hodis, S. H. K. Kang, Contemporary Educational Psychology, 61, (2020), doi: 10.1016/j.cedpsych.2020.101865

13. M.D.H. Rahiem, Children and Youth Services Review, 120, (2021), doi: 10.1016/j.childyouth.2020.105802

14. T.V. Maryshkina, A.N. Kalizhanova, Mir pedagogiki i psikhologii, 2(55), 120-139 (2021)

15. E.K. Gismatullina, Vestnik NGU. Seriya: Sotsial'no-ekonomicheskiye nauki, 12(1), 127-138 (2012)

16. S.L. Rubinshteyn, Osnovy obshchey psikhologii, 26 (2020)

17. M. M. Grigoryan, T. V. Suchkova, Professional'no-lichnostnoye razvitiye budushchikh spetsialistov $v$ srede nauchno-obrazovatel'nogo klastera: Materialy 14-oy

Mezhdunarodnoy nauchno-prakticheskoy konferentsii, Kazan', 28 maya 2020 goda, 159-162 (2020)

18. M. Ivanova., N. Mekeko, T. Kashkarova, \& N. Shlenskaya, Journal of Language and Education, 5(2), 67-77 (2019), https://doi.org/10.17323/jle.2019.9695

19. K. Chilingaryan, R. Gorbatenko, Procedia - Social and Behavioral Sciences, 214, 559564 (2015), doi: 10.1016/j.sbspro.2015.11.760

20. A. J.Moeller, T. Catalano, International Encyclopedia of the Social \& Behavioral Sciences (Second Edition), 327-332 (2015), doi: 10.1016/B978-0-08-097086-8.920828

21. D. H. Schunk, M. K. DiBenedetto, Contemporary Educational Psychology, 60, 2020, doi: 10.1016/j.cedpsych.2019.101832 